\title{
Primary caesarean section in multigravida
}

\section{Mohana Dhanapal Munusamy*, Subha Sivagami Sengodan, Kalaivarasi Umapathy Duraisamy}

Department of Obstetrics and Gynecology, Government Mohankumaramangalam Medical College Hospital, Salem, Tamil Nadu, India

Received: 22 December 2017

Accepted: 24 January 2018

\section{*Correspondence:}

Dr. Mohana Dhanapal Munusamy,

E-mail: doctormohana@gmail.com

Copyright: (c) the author(s), publisher and licensee Medip Academy. This is an open-access article distributed under the terms of the Creative Commons Attribution Non-Commercial License, which permits unrestricted non-commercial use, distribution, and reproduction in any medium, provided the original work is properly cited.

\begin{abstract}
Background: This study was done to analyse primary caesarean section in multigravida who had delivered vaginally. Indications for caesarean section were studied in relation to age, gravida, maternal and foetal morbidity.

Methods: This study was conducted in Goverment Mohankumaramangalam Medical College and Hospital, Salem. It was a retrospective study from September 2016 to August 2017.

Results: Most of cases were referred as an emergency. Most common age group was between 20-30 years. Majority were second gravida. Among the various indications for primary caesarean section in multigravida, foetal distress (18.12\%), hypertensive disorder complicating pregnancy (16.10\%), CPD (15.43\%), APH (12.08\%), malpresentation $(10.73 \%)$ were the common indications. In intraoperative complication PPH was most common (16.77\%). In postoperative complication fever was the most common (20.80\%). Still birth occurred in $10.06 \%$ of cases, 42 babies were admitted in NICU and babies had APGAR >7 (61.74\%).

Conclusions: Implementation of standard labour management strategies can decrease primary caesarean rate without compromising maternal and foetal safety. We must encourage early referral of high risk patient, so that the patient can reach higher centre earlier and proper management could be done before consequences become grave.
\end{abstract}

Keywords: Caesarean section, Foetal distress, Multigravida

\section{INTRODUCTION}

Caesarean delivery defined as delivery of foetus through incision on abdominal wall and incision on intact uterine wall. Multigravida means those who have had delivered once or more after the age of viability.

Primary caesarean section in Multipara means first caesarean section done in patients who had delivered vaginally once or more. Caesarean section is one of the commonly performed surgical procedure world wide. ${ }^{1}$

Safety of caesarean section has improved over decades due to improved anaesthetic techniques which has accounted for increased rate of caesarean section in the world. $^{2,3}$
The rate of caesarean section is increasing beyond the recommended level of 5-15 by WHO. Unnecessary caesarean section increases the maternal mortality.

Inspite of remarkable improvement in the safety of anaesthesia and surgical technique, caesarean section has higher risk of maternal morbidity and mortality when compared to normal vaginal delivery. There is no decrease in perinatal mortality with increase caesarean section rate.

This study was done to know the incidence of primary caesarean section in multigravida, to investigate the indication of primary caesarean section in multigravida and to study the intraoperative and post-operative complication. 


\section{METHODS}

It was a retrospective study, carried out at Department of Obstetrics and Gynecology, Government Mohankumaramangalam Medical College and Hospital, Salem, India from September 2016 to August 2017 on 149 cases. All cases of primary caesarean section with previous vaginal delivery, after satisfying the inclusion and exclusion criteria from Department of obstetrics and gynecology, was taken up for study.

\section{Inclusion criteria}

- Multigravida >28weeks (gravid two and above), Each of whom have had a previous vaginal delivery of live baby,

- Multiple pregnancy,

- $\quad$ Pregnancy with medical disorders.

\section{Exclusion criteria}

- Bad obstetric history

- Multigravida with previous caesarean section.

This is a retrospective study of 149 cases of primary caesarean section in multigravida admitted in Government Mohankumaramangalam Medical College and Hospital, Salem, India from September 2016 to August 2017. The obstetric theatre and labour ward records were reviewed to identify the patients who underwent caesarean section during the study period. From the case sheets the details regarding age of patient, gravida, gestational age, indications for caesarean section, intra operative and post-operative complications, sick new born admission, APGAR were noted.

\section{Statistical analysis}

All the information was gathered and the results were entered in case record form and keyed into SPSS computer software version 13.0 for windows and were analysed using statistical methods.

\section{RESULTS}

Total number of deliveries for the year September 2016 to August 2017 were 8,678. Number of LSCS were 4,472 .

Table 1: Age distribution.

\begin{tabular}{|ll|}
\hline Age & Percentage \\
\hline $21-25$ & 60.2 \\
\hline $26-30$ & 13.0 \\
\hline $31-35$ & 4.6 \\
\hline$>35$ & 0.3 \\
\hline
\end{tabular}

About 149 cases of primary caesarean section done in multipara during the period of one year were analysed and the results were as follows. Table 1 shows age distribution, majority were in the age group of 20-30yr (73.2\%), followed by $4.6 \%$ in the age group of $31-35 y$ rs and we had $0.3 \%$ of patients in above 35 age group.

About $96.3 \%$ patients were booked either in our hospital or in primary health centre or private hospital. $91.7 \%$ of patients were referral cases and $8.3 \%$ were booked in our hospital. Regarding gestational age, majority were in the GA of $36-40$ weeks $(59.06 \%), 12.08 \%$ were in the $28-32$ weeks GA, 32-36 weeks (17.44\%), more than 40 weeks GA $(11.40 \%)$.

Table 2: Gravida distribution.

\begin{tabular}{|ll|}
\hline GRA VIDA & Percentage \\
\hline G2 & 63.75 \\
\hline G3 & 20.13 \\
\hline G4 & 10.73 \\
\hline G5 & 5.3 \\
\hline
\end{tabular}

Table 2 shows gravida distribution, most of them were $2^{\text {nd }}$ gravida $(63.75 \%)$ and $3^{\text {rd }}$ gravida $(20.13 \%) .4^{\text {th }}$ gravida contributed to $10.73 \%$ of patients and $5.3 \%$ were $5^{\text {th }}$ gravida and above.

Table 3: Medical disorder.

\begin{tabular}{|ll|}
\hline Co -morbidity & Percentage \\
\hline Mild preeclampsia & 1.34 \\
\hline Severe pre-eclampsia & 9.39 \\
\hline AP eclampsia & 4.69 \\
\hline Chronic hypertension & 1.34 \\
\hline Anaemia & 44.83 \\
\hline Gestational diabetes & 2.68 \\
\hline Bronchial asthma & 6.04 \\
\hline Epilepsy & 1.34 \\
\hline
\end{tabular}

Table 3 shows co-morbid condition where anemia was the commonest around $44.83 \%$ and the same was treated by blood transfusion and Inj. Ironsucrose, followed by severe pre-eclampsia $9.39 \%$, AP eclampsia $4.69 \%$, gestational diabetes $2.68 \%$, whereas mild pre-eclampsia, chronic hypertension and epilepsy showed similar incidence of $1.34 \%$.

Table 4: Indications.

\begin{tabular}{|l|l|}
\hline Indication & $\%$ \\
\hline Foetal distress & 18.12 \\
\hline Hypertensive disorder complicating pregnancy & 16.10 \\
\hline CPD & 15.43 \\
\hline APH & 12.08 \\
\hline Malpresentation & 10.73 \\
\hline Non progression of labour & 10.06 \\
\hline Failed induction & 8.05 \\
\hline Multiple pregnancy & 4.02 \\
\hline GDM & 2.68 \\
\hline Cord prolapsed & 1.34 \\
\hline Gynaec disorder complicating pregnancy & 1.34 \\
\hline
\end{tabular}


Regarding indications foetal distress and hypertensive disorder complicating pregnancy were most common about $18.12 \%$ and $16.10 \%$ respectively.

In hypertensive disorder complicating pregnancy, antepartum eclampsia accounted for $6.04 \%$ of cases. CPD, APH and malpresentation were $16.10 \%, 12.08 \%$, $10.73 \%$ respectively.

Non-progression of labour was the indication in 15 patients $(10.06 \%)$, failed induction was the indication in 12 patients $(8.05 \%)$ mainly in post-dated and oligohydramnios.

Multiple pregnancy with the first twin in non-vertex presentation was contributing in $4.02 \%$ of patients.

In malpresentation breech presentation was more common in 10 patients mainly flexed breech, whereas 6 cases were transverse lie.

In gynaec disorder complicating pregnancy we had one multiple fibroid complicating pregnancy and UV prolapse complicating pregnancy, and cord prolapse occurred in two patients.

Table 5: Intra operative complications.

\begin{tabular}{|l|l|}
\hline Complication & Percentage \\
\hline PPH & 16.77 \\
\hline Extension of uterine wound & 7.38 \\
\hline Bladder injury & 0.67 \\
\hline Caesarean hystrectomy & 2.01 \\
\hline
\end{tabular}

In intra operative complication PPH (16.77\%) was more common. The extension of uterine wound occurred in $7.3 \%$ of cases mainly in obstructed labour cases. 3 cases proceeded to caesarean hysterectomy, in this two cases done for atonic PPH which was uncontrolled by medical management and uterine artery ligation. One caesarean hysterectomy was done for placenta accreta, for the same bladder injury occurred.

Table 6: Post operative complication.

\begin{tabular}{|l|l|}
\hline Post op complications & Percentage \\
\hline Fever & 20.80 \\
\hline UTI & 8.05 \\
\hline Wound infections & 18.79 \\
\hline Paralytic ileus & 7.38 \\
\hline Respiratory tract infection & 4.02 \\
\hline Wound resuturing & 9.39 \\
\hline Secondary PPH & 2.01 \\
\hline
\end{tabular}

Post operative complications occurred in $70.44 \%$ of patients where as $29.56 \%$ of patients did not have any complications. Among post operative complications the fever was most common complication $(20.80 \%)$ followed by wound infection $(18.79 \%)$, wound resuturing done in
$9.39 \%$ of patients. UTI occurred in $8.05 \%$ of cases and paralytic ileus in $7.38 \%$ of cases, respiratory tract infection and secondary PPH occurred in $4.02 \%$ and $2.01 \%$ respectively.

Table 7: Perinatal outcome.

\begin{tabular}{|llll|}
\hline Cases & Still birth & NICU admission & APGAR $>7$ \\
\hline 149 & 15 & 42 & 92 \\
\hline$\%$ & 10.06 & 28.18 & 61.74 \\
\hline
\end{tabular}

In present study, still birth happened in $10.06 \%$ of cases, 42 cases admitted in NICU and $61.74 \%$ of cases had APGAR $>7$.

\section{DISCUSSION}

About 149 cases of primary caesarean section done in multipara during the period of one year were analysed and the results were as follows.

Table 8: Perinatal outcome.

\begin{tabular}{|lll|}
\hline $\begin{array}{l}\text { Deliveries for the one } \\
\text { year }\end{array}$ & $\begin{array}{l}\text { No. of } \\
\text { cases }\end{array}$ & Percentage \\
\hline The & 8678 & \\
\hline LSCS & 4472 & 51.53 \\
\hline $\begin{array}{l}\text { Primary caesarean } \\
\text { section in multipara }\end{array}$ & 149 & 3.33 \\
\hline
\end{tabular}

Our hospital is tertiary care hospital and receive a good number of high risk emergency cases with inadequate or no antenatal care, so we have increased caesarean section rate.

In this study primary section rate in multipara was $3.33 \%$ where as in study by Agrawal $\mathrm{M}$ et al the rate was $9.65 \%$, and in study by Klein MD the rate was $0.51 \%{ }^{4}$

Analysis of age group shows that $73.2 \%$ of patients belong to the age group of 20-30 years, which is similar to a study by Karim et al, who showed $77 \%$ of cases in the same age group. In present study majority were emergency LSCS.

Table 9: Type of LSCS.

\begin{tabular}{|ll|}
\hline Type of LSCS & Percentage \\
\hline Emergency LSCS & 93.96 \\
\hline Elective LSCS & 6.04 \\
\hline
\end{tabular}

In current study foetal distress was the commonest indication for primary caesarean section accounted for $18.12 \%$ of cases which is comparable to the study by Jyothi Rao, who reported foetal distress of $17.4 \%$, in a study by Samal R et al, also reported foetal distress was the commonest indication in their study. 6,7 This high rate is also due to the increased detection of FHR abnormality alone as a measure of foetal distress. 
Hypertensive disorder complicating pregnancy was the second leading cause of caesarean section in multipara, which contributed to $16.10 \%$ of primary caesarean section. Antepartum eclampsia contributed to the $6.04 \%$ of caesarean section, whereas study by Birla $\mathrm{S}$ et al reported that AP eclampsia was responsible for $0.73 \%$ of cases in their study. ${ }^{8}$

CPD accounted for $15.43 \%$ of cases which is similar to study by Sharmila who reported $15.8 \% .^{9}$ In present study 7 cases of CPD where presented with obstructed labour and increased in maternal morbidity.

Multipara may still have CPD, since the foetus tent to increase in size. Antepartum haemorrhage was $12.08 \%$ in present study which is similar to study by Hemabindu who reported $11.2 \%{ }^{10}$ Malpresentation accounted for $10.73 \%$ of cases where as a study by Desai E reported $17.4 \%$ of cases of malpresentation. ${ }^{11}$

In present study non progression of labour accounted for $10.06 \%$ which is similar to study by Sonia Arogya Prakash, who reported $11.36 \% .^{12} 8.05 \%$ of primary caesarean section were done for failed induction.

Twin pregnancy ( $1^{\text {st }}$ twin non-vertex $)$ was the indication in $4.02 \%$ of cases. GDM accounted for $2.68 \%$ of cases mainly for the patients with large baby and high doses of Insulin. Gyneac disorder complicating pregnancy (one fibroid and one prolapse) and cord prolapse with live foetus accounted for $1.34 \%$ and $1.34 \%$ respectively. Still birth happened in $10.06 \%$ of cases which is similar to study by Saluja JK who reported $12 \%$ of still birth. ${ }^{13}$

Intra operative complications happened in $26.81 \%$ of cases, out of which atonic $\mathrm{PPH}$, stands out as most frequent complication $(16.77 \%)$, and study by Sams S reported atonic $\mathrm{PPH}$ was the commonest complication in her study. ${ }^{14}$

Extension of uterine wound $7.3 \%$ of cases mainly in obstructed labour, who were reported very late. Bladder injury occurred in one case of placenta accreta during caesarean hysterectomy. The Table 10 shows incidence of post operative complications in present study which is compared with study by Suresh A. ${ }^{15}$

Table 10: Comparison of post-operative complications.

\begin{tabular}{|lll|}
\hline $\begin{array}{l}\text { Post operative } \\
\text { complications }\end{array}$ & $\begin{array}{l}\text { Present } \\
\text { study }\end{array}$ & $\begin{array}{l}\text { Reference study } \\
\text { by Suresh A }\end{array}$ \\
\hline Fever & $20.80 \%$ & $6 \%$ \\
\hline UTI & $8.05 \%$ & $14 \%$ \\
\hline Wound infections & $18.79 \%$ & $14 \%$ \\
\hline Paralytic ileus & $7.38 \%$ & $4 \%$ \\
\hline $\begin{array}{l}\text { Respiratory tract } \\
\text { infections }\end{array}$ & $4.02 \%$ & $2 \%$ \\
\hline Wound resuturing & $9.39 \%$ & $6 \%$ \\
\hline Secondary PPH & $2.01 \%$ & $4 \%$ \\
\hline
\end{tabular}

\section{CONCLUSION}

Implementation of standard labour management strategies can decrease primary caesarean section rate without compromising maternal and foetal safety.

Increased in caesarean section is due to referral nature of hospital, unbooked patients. There are many cases where caesarean section becomes mandatory. They are contributing to increased total caesarean rate. Patient should be planned very judiciously after critical evaluation of circumstances. Good antenatal, intrapartum care, early referral will decrease the maternal and foetal morbidity.

We must encourage early referral of high risk patient, so that the patient can reach higher centre earlier and proper management could be done before consequences become grave.

Funding: No funding sources

Conflict of interest: None declared

Ethical approval: The study was approved by the Institutional Ethics Committee

\section{REFERENCES}

1. Awoyinka BS, Ayinde OA, Omigbodun AO. Acceptability of caesarean delivery to antenatal patients in a tertiary health facility in south-west Nigeria. J Obstet Gynecol. 2006 Jan 1;26(3):208-10.

2. Adeoye SI, Kalu CA. Pregnant Nigerian women's view of caesarean section. Nigerian J Clin Pract. 2011;43:276-9.

3. Penna L, Arulkumaran S. Cesarean section for nonmedical reasons. Int J Gynecol Obstet. 2003 Sep 1;82(3):399-409.

4. Agrawal M, Waydande S, Jadhav V, Bhave S. Frequency and indications of primary caesarean section inmultipara in tertiary care hospital. Int $\mathbf{J}$ Recent Trends Sci Tech. 2016;18(3):430-2.

5. Klein MD, Robbins R, Gabaeff L. Primary caesarean section in multipara. Am $\mathrm{J}$ Obstet Gynecol. 1963;87(2):242-52.

6. Rao J, Rampure N. Study of primary Caesarean section in multiparous women. JEMDS. 2013;2(24):4414-8.

7. Samal R, Palai P, Ghose S. Clinical study of Caeserean section in Multiparous women in a tertiary care hospital. IJRCOG. 2016;5(5):1506-9.

8. Birla S, Gupta M, Birla P, Sharma J. Comparison of incidence, indication and complication of primary Caeserean section in Primigravida and Multigravida. Int J Med Sci Edu. 2016;3(3):311-7.

9. Sharmila G, Nishitha C. Study of primary caesarean section in multi gravida. Asian Pac J Health Sci. 2016;3(4):89-94.

10. Himabindu P, Sundari MT, Sireesha KV, Sairam MV. Primary caesarean section in multipara. JDMS. 2015;14(5):22-5. 
11. Desai E, Leuva H, Leuva B, Kanani M. A study of primary Caesarean section in Multipara. Int J Reprod Contracept Obstet Gynecol. 2013;2(3):320-4.

12. Prakash SA, Vikram A, Raja Gopal K, Lavanya PS. Primary cesearean section in multigravidas. Int $\mathrm{J}$ Reprod Contracept Obstet Gynecol 2016;5:3849-52.

13. Saluja JK, Roy PK, Mahadik K. Study of primary caesarean section in multiparous women. NJIRM. 2014;5(2):27-9.

14. Sams S, Cicily TJ, Balachandran A. Institutional study of primary caeserean section among multigravida. J Med Sci Clini Res. 2017;5(4):2071320.

15. Suresh DY, Suresh D. A prospective comparative study of caeserean section in multiparous and primiparous women. Int J Pharma Bio Sci. 2017 Jul;8(3):890-5.

Cite this article as: Munusamy MD, Sengodan SS, Duraisamy KU. Primary caesarean section in multigravida. Int J Reprod Contracept Obstet Gynecol 2018;7:961-5. 